\title{
Effects of Total Mixed Fermentations with Bean Curd Dregs on Growth Performance of Growing Hanwoo Heifers
}

Jae Seok Woo', Sun Sik Jang', Seok Ki Im', Seok Dong Lee', Myeung Sik Lee', Jung Yong Park', Seong Koo Hong', Sung Sill Lee ${ }^{2}$ and Sang Min Lee"*

\author{
${ }^{1}$ National Institute of Animal Science, RDA, Pyeongchang, 232-950, Korea \\ ${ }^{2}$ Division of Applied Life Science, Gractuate School Gyeangsang National Univerity, Jinju, 660-701, Korea
}

Received August 5, 2011 /Revised September 21, 2011 /Accepted September 23, 2011

\begin{abstract}
This study was conducted to determine the effects of total mixed fermentation (TMF) with bean curd dregs on body weight gain, feed intake and body size of growing Hanwoo heifers. Thirty Hanwoo heifers, 6 months of age and weighing $125.9 \pm 12.0 \mathrm{~kg}$, were randomly allocated to 3 experimental groups of 10 animals each for a 6-month feeding trial. The groups were $\mathrm{T} 1$ (rice straw offered ad libitum with restricted $(1.7 \% \mathrm{BW} /$ day) concentrate), T2 (TMF only offered ad libitum) and T3 (TMF and rice straw offered ad libitum with restricted $(1.0 \% \mathrm{BW} /$ day) concentrate). TMF feeds were composed of $60 \%$ bean curd dregs, $16.5 \%$ corn meal, $10.4 \%$ wheat bran, $5 \%$ rice straw, $7 \%$ rice hulls, $0.5 \%$ urea matter, $0.5 \%$ magnesia lime and $0.1 \%$ lactic acid bacteria. The chemical composition and $\mathrm{pH}$ value of TMF feeds were measured at $0,24,48$ and $72 \mathrm{hr}$ after storage. In TMF with bean curd dregs, there were no differences in concentrations of $\mathrm{DM}, \mathrm{EE}$, and $\mathrm{CF}$ according to storage periouds. The ADF and NDF at $72 \mathrm{hr}$ of storage time showed a significant decrease (9.52 and $3.15 \%$, respectively) compared to $0 \mathrm{~h}$ of storage time $(p<0.05)$. The value of $\mathrm{pH}$ was gradually decreased during the storage periods. Body weight gain, feed intake and average daily gain were higher in the TMF groups (T2, T3) compared to the T1 group $(p<0.05)$. Changes in body size were also higher in the TMF groups compared to the T1 group $(p<0.05)$. Thus, the present results indicate that TMF with bean curd dregs may help improve growth performance in growing Hanwoo heifers.
\end{abstract}

Key words : Total mixed fermentation (TMF), bean curd dregs, Hanwoo heifers, growth performance

\section{서 론}

우리나라 한우산업은 외국 쇠고기의 수입 증가와 가축전염 병 발생, 원료사료 가격상승 및 한우사육 두수증가로 인해 쇠 고기 가격의 하락으로 위기에 직면해 있다. 이러한 한우산업 의 위기를 극복하기 위해서는 생산비의 가장 큰 비중을 차지 하는 사료비의 절감이 우선되어야 할 것이다. 생산비 절감을 위한 수단으로 농축산 부산물을 이용한 사료개발 연구가 활발 히 수행 중이다. 이 중 두부생산에 발생되는 비지박의 경우 이전에는 폐기물로 취급되어 환경오염과 폐기비용이 발생하 였지만, 최근에는 가축의 사료자원으로 활용되고 있다. 비지 박의 사료로서의 장점은 원료 수급이 원활한 편이고, 조단백 질 함량과 $\mathrm{TDN}$ 이 높아 영양학적 가치가 높은 반면 수분함량 이 매우 높고 부패가 쉽게 일어나는 단점도 있어 사료로 이용 시 발효 또는 건조 등의 처리가 요구된다고 하였다[13]. Wang 등[24]은 비지박 발효 및 비지박을 이용한 섬유질배합사료의 저장성 및 발효특성에 관한 연구에서 비지박 첨가 섬유질발효 사료가 저장성 및 발효특성에 있어 비지박의 발효 보다 우수

*Corresponding author

Tel : +82-33-330-0661, Fax : +82-33-330-0660

E-mail : sseangnim@korea.kr
한 것으로 보고하였고, 비지박과 같은 수분함량이 높은 부산 물의 저장성은 좋지 않다고 보고된 바 있다[19]. 또한 섬유질배 합사료에 미생물의 접종은 저장성 향상을 위한 건조와 같은 처리비용을 줄일 수 있고, 사료가치를 증진시키는 것으로 보 고되고 있다[17,18].

배합사료와 조사료를 혼합한 섬유질배합사료는 가축의 선 택취식을 방지하고, 반추위 $\mathrm{pH}$ 의 항상성을 유지할 수 있어 사료섭취량을 증가시키며 가축의 대사성 질병을 감소시킬 수 있다고 하였다 $[8,14,20]$. 섬유질배합사료에 유용미생물을 첨가 하여 발효시킨 섬유질발효사료는 영양소 이용성을 증진시키 고 가축의 기호성을 향상시키며[5], 반추위 내 acetate 생성량 을 감소시키고 propionate 생성량을 증가시킨다[10]고 하였 다. 비지박을 이용한 발효사료의 반추위 내 발효특성에 관한 연구에서도 가축의 생산성을 향상시킬 것으로 보고되었고[7], 또한 이전의 연구에서 배합사료와 조사료의 분리급여 보다 섬유질발효사료의 급여가 가축의 생산성을 향상시킨다고 하 였고, 임 등[6]의 연구에서도 Yeast를 접종한 비지박 위주 섬유 질발효사료가 거세우의 산육 및 수소의 사료요구율을 향상시 키는 것으로 보고된 바 있다.

따라서 본 연구에서는 비지박을 이용한 섬유질발효사료의 급여가 한우암소의 육성기 발육특성에 미치는 영향을 알아보 
고자 수행하였다.

\section{재료 및 방법}

\section{공시동물 및 사양관리}

생후 약 6 개월령(평균체중 $125.9 \pm 12.0 \mathrm{~kg}$ )의 한우 비육암소 30 두를 공시하여, 농촌진흥청 국립축산과학원 한우시험장에 서 처리구별 10 두씩 군사하여 6 개월간 사양시험을 수행하였 다. 배합사료는 하루에 2회 $(08: 00,16: 00)$ 균등분배하여 급여하 였고, TMF 및 볏짚은 자유채식 시켰다. 물과 미네랄 블록은 항시 섭취할 수 있도록 하였다. 15 일 간격으로 체중조사 후 사료량을 조절하였다.

\section{시험사료}

공시동물에게 급여한 배합사료는 시판되는 육성우 사료를 이용하였고, 조사료원으로 세절된 볏짚을 이용하였다. 처리구 에 급여한 섬유질발효사료는 배합비(Table 2)에 맞게 혼합하 여 제조하였고 $500 \mathrm{~kg}$ 저장용기에 담아 밀폐하여 48시간 저장 후 급여하였다. 사료 내 발효특성을 알아보기 위해 저장시간 별 $(0,24,48$ 및 72 시간) 개봉 후 용기 내 중간 부위의 시료(2 $\mathrm{kg}$ )를 수거하여 $25 \mathrm{~kg}$ 비닐용기에 진공포장기를 이용하여 밀 봉하여, 분석시까지 $-70^{\circ} \mathrm{C}$ 에 동결보존 하였다. 시험에 이용된 사료의 일반성분 및 섬유질발효사료의 배합비는 Table 1 및 2에 각각 나타내었다.

\section{시험설계}

시험구 배치는 배합사료(체중의 $1.5 \%$ )와 볏짚 급여구(T1), 섬유질발효사료(자유채식) 급여구(T2) 및 배합사료(체중의 $1.0 \%$ )와 섬유질배합사료(자유채식) 및 볏짚 급여구(T3)의 3 처 리 10 반복으로 완전 임의배치하여 발육(증체 및 체형변화) 변 화를 조사하였다.

\section{사료성분 및 $\mathrm{pH}$ 변화}

사료의 일반성분은 각각의 시료 $(2 \mathrm{~kg})$ 를 수집하여 $\mathrm{AOAC}[1]$ 방법에 따라 분석하였다. 사료 내 수분함량은 $105^{\circ} \mathrm{C}$

Table 1. Chemical composition of feedstuffs used in this experiment (DM basis)

\begin{tabular}{lccc}
\hline Item & Concentrate & $\mathrm{TMF}^{1)}$ & Rice straw \\
\hline Dry matter (\%) & 86.5 & 50.0 & 91.43 \\
Crude protein (\%) & 13.0 & 13.1 & 4.39 \\
Ether extract (\%) & 2.1 & 3.0 & 2.36 \\
Crude ash (\%) & 5.1 & 7.6 & 13.07 \\
Crude fiber (\%) & 4.6 & 17.8 & 29.57 \\
$\mathrm{TDN}^{2)}(\%)$ & 67.0 & 23.6 & 38.3 \\
\hline
\end{tabular}

${ }^{1}$ TMF: Total Mixed Fermentation.

${ }^{2)}$ TDN: Total digestible nutrients.
Table 2. Formula of Total Mixed Fermentation with bean curd dregs

\begin{tabular}{lc}
\hline Ingredients & Mixture (\%) \\
\hline Bean curd dregs & 60.0 \\
Corn meal & 16.5 \\
Wheat bran & 10.4 \\
Rice straw & 5.0 \\
Rice hulls & 7.0 \\
Urea matter & 0.5 \\
Magnesia lime & 0.5 \\
Lactic acid bacteria & 0.1 \\
\hline
\end{tabular}

에서 8 시간 동안 건조 후 건조 전 무게에서 뺀 값으로 조사하 였고, 무기물함량은 $550^{\circ} \mathrm{C}$ 에서 1 시간 동안 회화하여 측정하였 다. 조단백질 함량은 Kjeldahle법, 조지방은 Soxhelt법, NDF (Neutral detergent fiber, 중성세제불용성 섬유소)와 $\mathrm{ADF}$ (Acid detergent fiber, 산성세제 불용성 섬유소)의 함량은 Van Soest 등[23]의 방법에 따라 분석하였다. $\mathrm{pH}$ 변화는 $50 \mathrm{~g}$ 시료 에 멸균증류수 $450 \mathrm{ml}$ 를 넣어 10 배 희석하여 $\mathrm{pH}$ meter (Mettler Toledo, MP230)를 이용하여 측정하였다.

\section{사양성적 및 체형변화}

체중은 시험 개시일로부터 종료 시까지 우사 내에 위치한 우형기(CAS Korea, Newton HT-501A)를 이용하여 15일 간격 으로 오전 사료급여 전에 측정하였고, 증체량은 개시체중에서 측정된 값의 차로 구하였으며, 각 처리별 증체량의 평균값을 시험일수로 나누어 일당증체량을 구하였다. 사료섭취량은 오 전 사료 급여 전 잔량을 조사한 후 전날 급여량에서 뺀 값을 섭취량으로 계산하였다. 체형조사는 시험개시일로부터 종료 시까지 3개월 간격으로 체척기 및 줄자를 사용하여 조사하였 다. 체척치를 검정 요령에 따라 체고, 체장, 십자부고, 흥심, 흥폭, 흥위 및 요각폭 순으로 각각 측정하였다.

\section{통계처리}

본 시험에서 얻어진 성적들은 SAS (Statistical Analysis System software, 1999)를 이용하여 분산분석 및 처리구간 유 의성 $(p \times 0.05)$ 을 검증하였다.

\section{결과 및 고찰}

\section{발효특성 및 $\mathrm{pH}$}

섬유질발효사료(TMF)의 저장시간에 따른 성분 및 $\mathrm{pH}$ 의 변 화는 Table 3 및 Fig. 1에 나타내었다. 저장시간에 따른 비지박 을 이용한 섬유질발효사료의 건물, 조지방 및 조섬유의 함량 은 저장시간에 따라 차이는 보였지만, 유의적 차이는 없었다. 조단백질의 함량은 저장기간에 따라 저장 후 72 시간을 제외하 고 비슷한 경향을 나타내었고 저장 후 72 시간에서 유의적으로 
Table 3. Chemical composition of TMF feed according to storage time

\begin{tabular}{lcccc}
\hline \multirow{2}{*}{ Item } & \multicolumn{4}{c}{ Storage time (hr) } \\
\cline { 2 - 5 } & 0 & 24 & 48 & 72 \\
\hline Dry matter (\%) & $48.03 \pm 1.03^{3)}$ & $47.90 \pm 0.40$ & $48.33 \pm 0.59$ & $49.53 \pm 0.29$ \\
Crude protein (\%) & $11.18 \pm 0.09^{\mathrm{b}}$ & $11.73 \pm 0.25^{\mathrm{b}}$ & $11.72 \pm 0.24^{\mathrm{b}}$ & $13.00 \pm 0.25^{\mathrm{a}}$ \\
Ether extract (\%) & $2.31 \pm 0.38$ & $2.17 \pm 0.15$ & $2.22 \pm 0.34$ & $2.92 \pm 0.26$ \\
Crude fiber (\%) & $17.39 \pm 0.80$ & $17.25 \pm 0.51$ & $17.89 \pm 0.67$ & $17.81 \pm 0.49$ \\
Crude Ash (\%) & $7.16 \pm 0.15^{\mathrm{b}}$ & $7.58 \pm 0.07^{\mathrm{b}}$ & $7.74 \pm 0.12^{\mathrm{b}}$ & $7.78 \pm 0.14^{\mathrm{a}}$ \\
NDF $^{1)}$ & $62.97 \pm 0.13^{\mathrm{a}}$ & $59.48 \pm 0.44^{\mathrm{b}}$ & $52.94 \pm 0.87^{\mathrm{c}}$ & $53.45 \pm 0.38^{\mathrm{c}}$ \\
$\mathrm{ADF}^{2)}$ & $26.10 \pm 0.57^{\mathrm{a}}$ & $24.33 \pm 0.46^{\mathrm{b}}$ & $24.38 \pm 0.26^{\mathrm{b}}$ & $22.95 \pm 0.46^{\mathrm{b}}$ \\
\hline
\end{tabular}

${ }^{1)} \mathrm{NDF}$ : Neutral detergent fiber.

${ }^{2)}$ ADF: Acid detergent fiber.

${ }^{3)}$ Means \pm standard error of mean.

${ }_{a, b, c}$ Means with different superscripts in the same row differ significantly $(p<0.05)$.

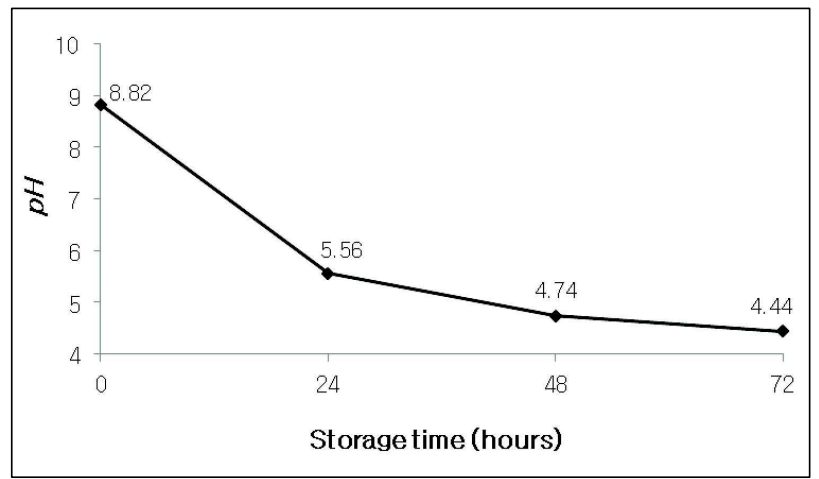

Fig. 1. $\mathrm{pH}$ changes of TMF feeds with bean curd dregs over storage time in anaerobic condition.

높았고 $(p<0.05)$, 조회분 역시 저장시간에 따라 비슷한 경향을 나타내었는데, 저장 후 72시간에서 유의적으로 높았다 $(p<0.05) . \mathrm{NDF}$ 및 $\mathrm{ADF}$ 함량은 시험 초기에 비해 저장시간에 따라 유의적으로 낮은 값을 나타내었는데 $(\beta \times 0.05)$, 시험종료 시 $\mathrm{NDF}$ 및 $\mathrm{ADF}$ 의 함량은 개시시 보다 각각 9.52 및 $3.15 \%$ 감소하였다. 비지박을 이용한 $\mathrm{TMF}$ 사료의 저장시간별 $\mathrm{pH}$ 의 변화에 있어서는 0 시간 $8.82 \pm 0.01$ 에서 24 시간에서 $5.56 \pm 0.01$ 으로 급격히 낮아졌고, 72 시간 경과 후 $4.44 \pm 0.01$ 로 지속적으 로 낮아지는 결과를 나타내었다(Fig. 1). Wang 등[24]의 연구 에서도 비지박을 이용한 섬유질발효사료에 lactic acid bacteria를 접종하여 발효시켰을 때 14 일 이후 lactic acid bacteria 및 효모의 수와 휘발성지방산(VFA)이 증가하였다고 보 고하였다. 이 등[21]은 섬유질배합사료 내 미생물(박테리아, 효모, 곰팡이)을 접종하였을 때 $\mathrm{NDF}$ 및 $\mathrm{ADF}$ 의 함량이 미생 물을 첨가하지 않은 대조구에 비해 감소하였다고 보고하였는 데 본 연구의 결과와 일치하였다. 하지만, 이 등[21] 은 조섬유 및 조회분의 함량이 감소한 것으로 보고하였는데 본 연구에 서는 조섬유는 변화가 없었고, 조회분은 증가한 것으로 나타 났다. 발효사료 내 $\mathrm{pH}$ 의 변화는 배양초기에 급격하게 낮아지 다 일정 수준에서 발효시간에 따른 $\mathrm{pH}$ 변화가 적었는데 다른
연구에서 비지박을 이용한 발효사료의 $\mathrm{pH}$ 변화에서 시간이 경과함에 따라 낮아지는 경향을 나타내었지만, 저장 14 일과 56 일에서 $\mathrm{pH}$ 의 수준이 3.83 3.90로 변화가 적었다[24]는 연구 결과와 유사하였다. Lactic acid bacteria의 첨가는 $\mathrm{pH}$ 를 낮추 는 작용을 한다고 보고하였고[11], 이후에 $\mathrm{pH}$ 변화가 적은 것 은 발효사료 중 존재하는 live yeast의 $\mathrm{pH}$ 의 조절효과 $[3,16]$ 로 판단된다.

\section{체중, 일당증체량 및 사료섭취량}

비지박을 이용한 섬유질발효사료를 급여한 한우 육성 암 소의 체중, 일당증체량, 사료섭취량을 조사하였다(Table 4). 한우 육성 암소의 개시 시 체중은 처리구별 차이가 없었지 만, 시험 종료 시 체중은 각각 226.5, 297.2 및 $307.6 \mathrm{~kg}$ 으로 $\mathrm{TMF}$ 급여구(T2)와 TMF와 배합사료 혼합급여구(T3)가 유의 적으로 높았고, 배합사료 급여구(T1)가 가장 낮았다( $p<0.05)$. 일당증체량은 각 처리구별로 $0.52,0.84$ 및 $0.91 \mathrm{~kg}$ 으로 체중 변화와 마찬가지로 TMF 급여구들에 비해 분리 급여구(T1) 에서 유의적으로 낮게 나타났다( $p<0.05)$. 건물섭취량은 $\mathrm{T} 3$ 처 리구가 $7.33 \mathrm{~kg}$ 으로 가장 높았고, 분리 급여구(T1)에서 유의 적인 차이는 없었지만, 낮은 경향을 나타내었다. 사료요구율 에 있어서는 TMF 급여구(T2, T3) 간 비슷한 경향을 나타내 었고(8.33 vs 8.09), $\mathrm{T} 1$ 처리구에서 유의적으로 높았다 $(p<0.05) . \mathrm{T} 1$ 처리구의 경우 $\mathrm{TMF}$ 처리구 보다 낮은 증체, 일 당증체량 및 사료섭취량의 결과를 나타내었는데, 이는 $\mathrm{T} 1$ 처 리구의 제한된 배합사료 및 볏짚 섭취량이 자유채식의 섬유 질발효사료(TMF) 보다 건물섭취량이 적어 섭취한 영양소 수 준이 낮았기 때문인 것으로 판단된다. 사양조건에 따라 달라 질 수 있고 육량 및 육질이 달라지고[4], 특히 사료의 영양수 준에 따라 근육의 발달에 영향을 준다고 하였다[7]. 본 연구 의 결과는 배합사료 조사료 분리 급여구 보다 섬유질배합사 료 급여구가 향상된 성장률을 보인다는 강 등[22]의 연구와 일치하였고, 박 등[2]의 연구에서 섬유질발효사료의 급여가 수소에 있어 배합사료 조사료 분리 급여구 보다 비육기 사료 
Table 4. Body weight, average daily gain and dry matter intake of growing Hanwoo heifers

\begin{tabular}{|c|c|c|c|}
\hline Item & $\mathrm{T} 1^{1)}$ & $\mathrm{T}^{2)}$ & $\mathrm{T}^{3)}$ \\
\hline Initial $\mathrm{BW}^{4}(\mathrm{~kg})$ & $123.50 \pm 2.66^{7)}$ & $128.95 \pm 3.03$ & $125.25 \pm 5.35$ \\
\hline Final BW $(\mathrm{kg})$ & $226.50 \pm 6.79^{b}$ & $297.20 \pm 4.29^{\mathrm{a}}$ & $307.60 \pm 7.08^{\mathrm{a}}$ \\
\hline $\mathrm{ADG}^{5)}(\mathrm{kg})$ & $0.52 \pm 0.03^{b}$ & $0.84 \pm 0.02^{\mathrm{a}}$ & $0.91 \pm 0.02^{\mathrm{a}}$ \\
\hline \multicolumn{4}{|l|}{ Feed intake $(\mathrm{kg})$} \\
\hline Concentrate & 2.56 & - & 2.10 \\
\hline Total Mixed Fermentation & - & 13.93 & 10.26 \\
\hline Rice straw & 3.59 & - & 0.42 \\
\hline $\mathrm{DMI}^{6)}(\mathrm{kg})$ & 5.60 & 6.96 & 7.33 \\
\hline Feed conversion ratio $(\mathrm{kg})$ & $11.21 \pm 0.73^{\mathrm{a}}$ & $8.33 \pm 0.23^{b}$ & $8.09 \pm 0.21^{\mathrm{b}}$ \\
\hline
\end{tabular}

${ }^{1} \mathrm{~T} 1$ : Rice straw offered ad libitum with restricted (1.7\% BW/day) concentrate.

${ }^{2)}$ T2: TMF only offered ad libitum

${ }^{3)}$ T3: TMF and rice straw offered ad libitum with restricted (1.0\% BW/day) concentrate.

${ }^{4)}$ BW: Body weight.

${ }^{5)}$ ADG: Average daily gain.

${ }^{6}$ DMI: Dry matter intake.

${ }^{7)}$ Means \pm standard error of mean

${ }^{a, b}$ Means with different superscripts in the same row differ significantly $(p<0.05)$.

Table 5. Body size of growing Hanwoo heifers

\begin{tabular}{lccc}
\hline \multicolumn{1}{c}{ Item } & $\mathrm{T} 1^{1)}$ & $\mathrm{T} 2^{2)}$ & $\mathrm{T}^{3)}$ \\
\hline Initial & & & $94.00 \pm 0.73$ \\
Withers height (cm) & $93.80 \pm 0.95^{4)}$ & $94.00 \pm 1.15$ & $92.10 \pm 0.98$ \\
Body length (cm) & $94.10 \pm 1.11$ & $94.80 \pm 1.63$ & $96.30 \pm 0.63$ \\
Height at hip cross (cm) & $96.10 \pm 0.85$ & $96.60 \pm 1.51$ & $44.60 \pm 0.56$ \\
Depth of chest (cm) & $44.00 \pm 0.70$ & $43.70 \pm 0.72$ & $25.80 \pm 0.61$ \\
Chest width (cm) & $25.20 \pm 0.73$ & $25.50 \pm 0.48$ & $119.40 \pm 1.41$ \\
Chest girth (cm) & $120.60 \pm 1.49$ & $118.60 \pm 2.07$ & $21.90 \pm 0.31$ \\
Hip width (cm) & $21.20 \pm 0.20$ & $21.10 \pm 0.38$ & $110.70 \pm 0.72^{\mathrm{a}}$ \\
Finish & & & $123.40 \pm 1.38^{\mathrm{a}}$ \\
Withers height (cm) & $106.10 \pm 1.15^{\mathrm{b}}$ & $111.80 \pm 1.03^{\mathrm{a}}$ & $114.00 \pm 0.93^{\mathrm{a}}$ \\
Body length (cm) & $113.90 \pm 0.82^{\mathrm{b}}$ & $126.80 \pm 1.56^{\mathrm{a}}$ & $58.70 \pm 0.70^{\mathrm{a}}$ \\
Height at hip cross (cm) & $109.80 \pm 1.08^{\mathrm{b}}$ & $115.30 \pm 1.17^{\mathrm{a}}$ & $36.10 \pm 0.53^{\mathrm{a}}$ \\
Depth of chest (cm) & $54.60 \pm 0.62^{\mathrm{b}}$ & $57.80 \pm 0.66^{\mathrm{a}}$ & $160.70 \pm 1.25^{\mathrm{a}}$ \\
Chest width (cm) & $33.10 \pm 0.74^{\mathrm{b}}$ & $37.50 \pm 0.82^{\mathrm{a}}$ & $36.80 \pm 0.53^{\mathrm{a}}$ \\
Chest girth (cm) & $145.70 \pm 2.02^{\mathrm{b}}$ & $160.00 \pm 2.05^{\mathrm{a}}$ & $36.50 \pm 0.31^{\mathrm{a}}$ \\
Hip width (cm) & $32.70 \pm 0.30^{\mathrm{b}}$ & & \\
\hline
\end{tabular}

${ }^{1)}$ T1: Rice straw offered ad libitum with restricted (1.7\% BW/day) concentrate.

${ }^{2)}$ T2: TMF only offered ad libitum

${ }^{3)}$ T3: TMF and rice straw offered ad libitum with restricted (1.0\% BW/day) concentrate.

${ }^{4)}$ Means \pm Standard error of mean.

${ }^{a, b}$ Means with different superscripts in the same row differ significantly $(p<0.05)$.

효율이 개선되고 일당증체량이 증가하였다는 연구와도 일치 하였다. 또 다른 연구에서도 비육기 거세우 및 수소에 급여 한 발효사료가 분리 급여구에 비해 일당증체량과 사료요구 율을 향상시킨다고 하였고[6], 분리 급여구 보다 섬유질배합 사료가 비육후기 거세한우의 반추위 발효를 안정시키고 산 육성 및 육질등급을 향상시키며[12], 반추위발효과정 및 영 양소 이용효율 측면에서 우수하다고 하였다 $[9,13]$.

\section{체형변화}

육성기 한우 암소의 체형조사는 체고, 체장, 십자부고, 흥심, 흥폭, 흥위 및 요각의 순서로 조사하였고, 결과는 Table 5에 나타내었다. 시험개시(생후 6개월령) 시 각 처리구별 체형의 크기는 비슷하였지만, 시험종료(생후 12개월령) 시 체형변화 에 있어서 TMF 급여구(T2) 및 배합사료와 TMF 혼합 급여구 (T3)가 체고, 십자부고, 체장, 흥심, 흥폭, 흥위 및 요각에 있어 
유의적으로 높은 결과를 나타내었고( $p \times 0.05), \mathrm{T} 2$ 및 T3처리구 간 결과에서는 흥폭을 제외한 다른 부위에서는 $\mathrm{T} 2$ 처리구가 높았지만 유의적 차이는 나타나지 않았다. 이러한 결과는 육 성기 때 단백질과 에너지 등의 영양소 섭취량이 성장에 영향 을 준 것으로 판단되며, 사료섭취량의 결과에서 알 수 있듯이 건물섭취량이 낮은 배합사료 볏짚 급여구(T1)의 영양소 섭취 가 TMF 급여구(T2, T3)에 비해 에너지와 단백질 등의 영양소 부족이 발육에 영향을 준 것으로 생각된다[15].

\section{References}

1. A.O.A.C. 1995. Official method of analysis. 16th eds. Association of Official Analytical Chemists. Washington, DC. USA.

2. Park, B. K., J. M. Gil, J. B. Kim, B. J. Hong, C. S. Ra, and J. S. Shin. 2003. Effects of Fermented Feedstuff with Wet Brewer's Grain and Soybean on Fattening Performance and Carcass Grade in Hanwoo Steers. J. Anim Sci. Technol. 45, 397-408.

3. Chaucheyras, F., G. Fonty, G. Bertin, and P. Gouet. 1995. In vitro $\mathrm{H}_{2}$ utilization by a ruminal acetogenic bacterium cultivated alone or in association with an archea methanogen is stimulated by a probiotic strain of Saccharomyces cerevisiae. Appl. Environ. Microbiol. 61, 3466-3467.

4. Crouse, J. D., L. V. Cundiff, R. M. Koch, M. Koohmaraie, and S. C. Seidman. 1989. Comparisons of bos indicus and bos taurus inheritance for carcass beef characteristics and meat palatability. J. Anim Sci. 67, 2661-2668.

5. Li, D. Y., J. Y. Ko, N. J. Choi, Sang S. Lee, J. Y. Song, S. Y. Lee, S. H. Park, H. G. Sung, and J. K. Ha. 2003. Effects of types of TMR on rumen fermentation characteristics and nutrients digestibility in sheep. J. Anim Sci. Technol. 45, 805-812.

6. Lim, G. Z, C. H. Kim, S. J. Ohh, K. I. Sung, H. S. Kim, J. D. Kim, D. J. Hong, and J. S. Shin. 2001. Effects of alcohol-fermented feedstuffs on growth performance and blood metabolites in Hanwoo. J. Anim Sci. Technol. 43, 881-894.

7. Guenther, J. J., D. H. Bushman, L. S. Pope, and R. D. Morrison. 1965. Growth and development of the major carcass tissues in beef calves from weaning to slaughter weight, with Reference to the effect of plane of nutrition. J. Anim Sci. 24, 1184-1191.

8. Harrison, J. H., R. E. Riley, and K. A. Long. 1989. Effect of type and amount of buffer addition to grass silage-based total mixed rations on milk production and composition. J. Dairy Sci. 72, 1824-1830.

9. Shin, J. S., G. Z. Lin, and B. W. Kim. 2008. The effect of alcohol fermented feedstuff made of byproducts on fermentation characteristics and dry matter disappearance in the rumen. J. Korean Grassl. Forage Sci. 28, 49-60.

10. Kawanishi, R. 1989. Studies of livestock. 12th eds., pp1374-1376.
11. Kiazilsimsek, M., R. J. Schmidt, and L. Kung Jr. 2007. Effects of a mixture of lactic acid bacteria applied as a freeze-dried or fresh culture on the fermentation of alfalfa silage. J. Dairy Sci. 90, 5698-5705.

12. Kim, K. H., K. S. Kim, S. C. Lee, Y. G. Oh, C. S. Chung, and K. J. Kim. 2003. Effects of total mixed rations on ruminal characteristics, digestibility and beef production of Hanwoo steers. J. Anim. Sci. Technol. 45, 387-396.

13. Sung, K. I. 2001. Efficient use of the Agri-byproducts. pp 61-86, National Institute of Animal Science, RDA.

14. Kellems, R., O. R. Jones, D. Andrus, and M. V. Wallentine. 1991. Effect of moisture in total mixed rations on feed consumption and milk production and composition in Holstein cows. J. Dairy Sci. 74, 929-932.

15. Martin, T. G., T. W. Perry, M. T. Mohler, and F. H. Owens. 1978. Comparison of four levels of protein supplementation with and without oral diethylstilbestrol on blood plasma concentrations of testosterone, growth hormone and insulin in young bulls. J. Anim Sci. 49, 1489-1496.

16. Nisbet, D. J. and S. A. Martin. 1991. Effect of a saccharomyces cerevisiae culture on lactate utilization by the ruminal bacterium selenomonas ruminantium. J. Anim Sci. 16, 4928-4633.

17. Nishino, N., H. Harada, and E. Sakaguchi. 2003. Evaluation of fermentation and aerobic stability of wet brewers' grains ensiled alone or in combination with various feeds as a total mixed ration. J. Sci. Food Agric. 83, 557-563.

18. Nishino, N. and H. Hattori. 2007. Resistance to aerobic deterioration of total mixed ration silage inoculated with and without homofermentative or heterofermentative lactic acid bacteria. J. Sci. Food Agric. 87, 2420 2426.

19. Niwa, Y. 2001. Silage making and utilization of high-moisture byproducts. 4 . Making silage from tofu cake and utilization. Grassl. Sci. 47, 323-326.

20. Nocek, J. E., R. E. Steele, and D. G. Braund. 1986. Performance of dairy cows fed forage and grain separately versus a total mixed ration. J. Dairy Sci. 69, 2140-2147.

21. Lee, S. J., N. H. Shin, H. S. Jung, Y. H. Moon, S. Lee, and S. S. Lee. 2009. Effects of supplemental synbiotics composed of anaerobic bacteria, yeast and mold on the change of chemical composition and fermentation characteristics of total mixed ration for cattle. J. Life Sci. 19, 241-248.

22. Kang, S. W., K. S. Ki, Y. K. Oh, K. H. Kim, and C. W. Choi. 2005. Effects of roughage feeding type during the growing and early-fattening periods on growth performance, feed efficiency and carcass characteristics in Holstein steers. J. Anim Sci. Technol. 47, 769-782.

23. Van Soest, P. J., J. B. Robertson, and B. A. Lewis. 1991. Methods for fiber, neutral detergent fiber, and non starch polysaccharides in relation to animal nutrition. J. Dairy Sci. 74, 3583-3597.

24. Wang, F. and N. Nishino. 2008. Ensiling of soybean curd residue and wet brewers grains with or with other feeds as a Total Mixed Ration. J. Dairy Sci. 91, 2380-2387. 


\section{초록 : 비지박을 이용한 섬유질발효사료의 급여가 육성기 한우암소의 발육에 미치는 영향}

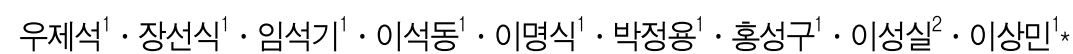

('농촌진흥청 국립축산과학원, ${ }^{2}$ 경상대학교 응용생명과학부)

본 연구는 비지박을 이용한 섬유질발효사료(TMF) 급여가 육성기 한우 암소의 증체, 사료섭취량 및 체형변화에 미치는 영향을 구명하기 위하여 수행하였다. 6 개월령 한우 암소 30 두(평균체중 $125.9 \pm 12.0 \mathrm{~kg}$ )를 공시하여 3처리 로 각각 10 마리씩 완전 임의배치하여 6 개월간 사양시험을 수행하였다. 처리구는 $\mathrm{T} 1$ (볏짚 자유급여와 배합사료 (체중 $1.7 \%$ /일) 제한급여구), $\mathrm{T} 2$ (TMF 자유 급여구) 및 $\mathrm{T} 3$ (TMF, 볏짚 자유급여와 배합사료(체중 $1.0 \%$ /일) 제한 급여구)로 수행하였다. 섬유질발효사료는 비지박 $60 \%$, 옥분 $16.5 \%$, 밀기울 $10.4 \%$, 볏짚 $5 \%$, 왕겨 $7 \%$, 요소 $0.5 \%$, 고토석회 $0.5 \%$, Lactic acid bacteria $0.1 \%$ 를 첨가하여 제조하였다. 섬유질발효사료의 화학적 성분과 $\mathrm{pH}$ 값은 저 장 $0,24,48$ 및 72 시간에 측정하였다. 비지박을 이용한 $\mathrm{TMF}$ 의 저장기간에 따른 결과에서 건물, 조지방, 및 조섬유 의 함량은 차이가 없었다. 저장 72 시간에서 $\mathrm{ADF}$ 및 $\mathrm{NDF}$ 함량은 0시간에서 보다 각각 9.52 및 $3.15 \%$ 유의적으로 감소하였다( $p<0.05) . \mathrm{pH}$ 또한 저장시간에 따라 점점 감소하였다. 체중, 사료섭취량 및 일당증체량은 $\mathrm{TMF}$ 급여구 (T2, T3)에서 T1급여구 보다 높았다( $p<0.05)$. 체형변화에 있어서도 T1처리구 보다 TMF 급여구가 높았다( $p<0.05)$. 따라서 본 연구의 결과 비지박을 이용한 TMF 사료의 급여는 육성기 한우 암소의 발육을 향상시키는 것으로 나타 났다. 